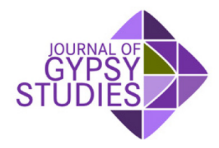

DOI: https://doi.org/10.33182/jgs.v2.i1.614

Article history: Received 27 February 2019 Accepted 7 December 2019

\title{
Early Marriage and Education Drop Out in Traditional Roma Communities in Transylvania Christina Velentza ${ }^{¥}$
}

\begin{abstract}
This research attempts to analyze the phenomenon of early marriage in traditional Roma communities in Transylvania, Central Romania, and its impact on the education of Roma children. The methodology of this paper is a reflection of a field work conducted in the region of Transylvania, Romania and mainly the city of Târgu Mureş (Tirgu Mures) the period February-July 2012, following several meetings and interviews with policy makers, representatives from local authorities, civil society, academics, political parties and representatives of traditional Roma communities and local schools. The organization that hosted me and facilitated me in my fieldwork is the NGO Liga Proeuropa and its President Smaranda Enache and her team. This work is a result of my personal interaction with some of the local communities in the region (Tírgu Mures, Sighişoara, Alba Iulia, Brasov, Sibiu) as well as the capital Bucharest which I had the opportunity to visit at that period of time. The project was funded by a small European grant (Leonardo da Vinci). The town of Tirgu Mures is where I was based, since the largest number of traditional Gabor Roma who still apply early marriages can be found there.
\end{abstract}

Keywords: Transylvania; Roma; early marriage; Romania; Gabor Roma.

\section{Roma community in Romania}

Sociologists and Roma community leaders estimate that the total number of Roma reaches 1,5-2 million persons, which makes 9,22\% of the total Romanian population. In Romania, the Roma are an officially recognized ethnic minority represented in the parliament. Traditional Roma communities have some of the characteristics such as: Large family with several members, common household of different generations, patriarchal decision making, women generally work in household, men assure the income and the leadership of the family. Roma groups in Romania can be found as: Aurari (Goldsmiths), Argintari (Silversmiths), Arămari (Tinker), Cocalari, Cărămidari (Brick Makers), Covatari, Cositorari (Sieve Makers), Carbunari, Fierari (Blacksmiths), Florarii (Florists), Gunoieri (Garbage carriers), Cehara, Corturarii (Roma living in tents), Corsarii (Basket Makers), Cosarii (Chimny Sweepers), Lemnari (Carpenters), Lingurari, Lă̌eţ, Geambagii/Lovari, Măturarii (Sweepers), Pieptănari (Comb Makers), Penari (Add chicken feathers), Rudarii, Racarii (Catch crabs), Olănari (Tiles

¥ Dr Christina Velentza, Athens Bar Association, Athens, Greece \& Koc University, Istanbul, Turkey. E-mail: velentza_x@hotmail.com. 
Makers), Telanii (Patavara), Ursari (Bear Leaders), Caldărari (Kaldarashi), Turkish Muslim Roma, Breastfeaders, Fortune-tellers, Healers, Whishes, Fiddlers, Zlatari, Silk Gypsies, Meseriaşii (Crafts men), Romungre.

\section{An early marriage: how it takes place and which communities practice it?}

This research attempts to analyze the phenomenon of early marriage in traditional Roma communities in Transylvania, Central Romania and its impact on education drop out in these communities. Early marriage is practiced by almost 7.000 families, $20 \%$ of the total Roma community in Romania 1 and mainly Kaldarasi Roma community(Romanian speaking) and Gabor Roma2 (Hungarian speaking) practice it. ${ }^{3}$

According to our data, early marriage takes place in a traditional way which has no legal validity as it is forbidden by Romanian law ${ }^{4}$, it is considered as a 'pre-marriage contract' between the two families who decide to proceed with the marriage. Early marriage is not a marriage per se, it is simply an engagement. This ensures the girl's integrity, originated by the protective role of the father within the deeply patriarchic Roma society. In that sense, early marriage takes place in the form of a 'promise' between the families, usually when children are at the age of 2-8 years old with the expectation that the marriage will take place when young girls reach 12-13 years old and young boys 13-15 years old. In legal terms, we could name this as a "promising" legal act with no legal results. In the communities practicing early marriage, the marriage is seen important to preserve the group's identity and prevent assimilation. The marriage takes place between children belonging to the same community, wealth and status of the families involved is a determinant factor for the early marriage.

\footnotetext{
${ }^{1}$ According to available data sociologists and Roma community leaders, the total number of Roma does not surpass $1.5-2$ million $(9,22 \%$ of total population of Romania, unofficial registration) and they are the second biggest ethic minority of Transylvania after hungarian minority.

${ }^{2}$ Gabor's origins place is where our fieldwork took place, in the area of Tírgu Mureş (Marosvásárhely in Hungarian language), Mureş in hungarian), Mureş in Transylvania. Their mother tongue is hungarian and they are famous for their involvement in traditional romani art and business, from generation to generation. More information here: http://romafacts.uni-graz.at/index.php/culture/culture-3/the-gabor-intransylvania--romania. Other Roma communities named after their occupation in Romania are: Aurari, Argintari, Arămari, Cocalari, Cărămidari), Covatari, Cositorari Cărbunari, Fierari, Florarii, Gunoieri, Cehara, Corturarii, Corsarii, Cosarii, Lemnari, Lingurari, Lăieți, Geambagii/Lovari, Măturarii, Pieptănari, Penari , Rudarii, Racarii, Olănari, Telanii, Ursari, Căldărari (Kaldarashi), muslim Roma of Turkish origin, self-educated violinists, curators, artisans (Meseriaşii), Romungre.

3 Kalderash (Căldărari in romanian language, Kalderash in romani, кomлspbr (Kotlyary) in ukrainian

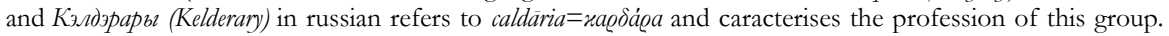
Their number is estimated in 200.000 in Romania. Big groups moved from Romania to Ukraine in the past. They are very well known for their traditional costumes in Transylvania (red traditional skirts for women).

${ }^{4}$ Art. 4, Law No. 4/1953 Family Code - Issuance of a marriage permit: 'On reasonable grounds, the child who has attained the age of sixteen can marry based on a medical opinion, with the consent of his/ her parents or, where appropriate, of his/her guardian and with the permission of the general department for social care and child protection, in which territorial jurisdiction has his/ber domicile."
}

TPLondon.com/JGS 
Until the marriage takes place, the tradition says that the young girl stays with her husband-to-be's family in order for the young couple to get used to each other and be prepared for their common life. As representative of Roma communities argue, the two young children are taught to grow up as 'brothers and sisters' and being loved by the young boy's family. Usually, young girls give birth to their first child at the age of 14-16 years old. Giving birth at a young age is common within traditional Roma culture, girl's integrity, purity of woman and inequality, patriarchy is defining this too. Based on our findings, early marriage is often linked with Roma tradition, poverty, education drop-out and lack of opportunities for young people. Girl's virginity is a prerequisite for the marriage and some argue that early marriage is the way for the traditional Roma families to preserve their wealth.

\section{Legal and institutional framework on marriage and children's rights in Romania}

Legally speaking, an early or forced marriage is a "Marriage consumed under the legal age of 18 as provided by the Romanian Constitution, a marriage between minor partners as they do not exercise fully the freedom of choice when entering into an early marriage union." Marriage consummated under the age of maturity is defined by the Penal Law as rape (art. 198: sexual intercourse with a minor, art. 199: enticement).

Romanian legal system ensures protection of children's rights under the following provisions: art. 48, 49 Romanian Constitution, art. 1, 3, 4, 101 of Family Code 1993, art. 198, 199 Penal Code 1997 and the Law No. 272/2004 on the protection and promotion of the child's rights (art. 4, 24, 85, 90). More specifically:

- Art. 198 Penal Code: "Sexual intercourse, of any nature, with a person of the other sex or of the same sex, who has not reached the age of 15, shall be punished by strict imprisonment from 3 to 10 years and the probibition of certain rights"

— Art. 199 Penal Code: "An act of a person, who, by promises of marriage, entices a female person under the age of 18 to have sexual intercourse with him, shall be punished by 1 to 5 years imprisonment"

The existence of institutions to promote Roma rights at national level such as the National Authority for the protection of family and children's rights, Ministry of Education which cooperates with the monitoring body of schools at local level, the Ministry of Public Health and the Ministry of Public Administration as well as the creation of relatively new ones such as the National Agency for Roma people is a positive step. The implementation of the first public policies as well as the openness of some institutions to partnerships and participation to interdisciplinary work is welcoming. 


\section{Velentza}

However, inadequate implementation of programs and the protection of children abused during these practices demands more political will and concrete commitments at national and local level. A comprehensive policy and efficient mechanisms focusing on early marriage prevention remains a challenge for all stakeholders concerned. Additional need to be taken including information campaigns on early pregnancies, violations of children's rights, gender-based violence and school drop-out. Education, awareness-raising and counseling provided by the existing state institutions seems necessary. Based on our findings, the institutions below are the ones more engaged in the implementation of programs promoting intercultural education and combating discrimination amongst Roma communities:

- Ministry of Education, Research, Youth and Sports (County School Inspectorates and County Offices for Roma Issues):

Educational policies are implemented at local level. There is a developed system of education in minority mother tongues, from kindergarten to University. Currently, implementation of the program "Everyone goes to kindergarten-everyone goes to school" is implemented with main aim to prevent early dropping out in 420 disadvantaged communities, with high percentage of Roma population in rural areas/small cities. Other large-scale programs implemented are: "School of the second chance", "School after School" and "School of the Mothers-in-Law".

- Ministry of Public Health: Early pregnancies are in the center of attention but there is no reflection of the ethnic background or the causes. The Public Health Authority representing the Ministry in each county implement policies and national public health programs at local level.

- Ministry of Administration and Interior: Police intervention in wedding ceremonies (cases of early marriages) is frequent as a result of media involvement.

At local level, things work a bit differently, the direct link between local representatives and community leaders and members can have direct and beneficial results for the communities. Following our interview with the Roma representative in the Prefecture office of Târgu Mures, Mr Florin Hajnal on 02 May 2012 he stated that "The best things are aimed to happen at local level' and favored coordination of authorities and communities at local level as a means to get more tangible results and impact for the communities. This is the existing structure of cooperation between the communities and the authorities at local level:

- There are three different categories of experts involved in the consultation process within the communities: School mediators, Health mediators and experts on Roma issues. 
- There is one person on Roma issues consulting within the Prefecture. There are 42 consultants in the whole Mures, county. There is ongoing cooperation between the Mayor's office and the National Agency for Roma (ANR) in order to address problems and issues that the communities face at local and regional level.

The National Strategy for Roma integration (2012-2020) ${ }^{5}$, based on EU principles along with the values of Roma people is the cornerstone of promoting rights of Roma communities as well as social cohesion in Romanian society. Romania's national Roma integration strategy aims to eliminate poverty and social exclusion through targeted education, employment, healthcare and housing policies. The strategy aims to ensure that Roma children go to school, with a special focus on girls, and ending segregation in schools. It also aims to improve Roma's access to public services and basic infrastructure. ${ }^{6}$

One of our interviewees stressed that the strategy "should be implemented by all stakeholders involved as it is a development plan for Roma people and a means to suggest advice to Roma communities"7. In T. Mures, area, an interviewee stated that there is an inadequate implementation of the strategy and this is a challenge for the communities in the city as "It is upon each Mayor's discretion to implement and follow it" and there is no obligation or sanctions if not followed properly. Also, he stated that"It is challenging to get all the Roma communities together" 8 as T. Mures, is divided into five different parts with a wide range of different communities and minorities, the critique is that each part should have its own representative to better address problems and challenges envisaged by the communities.

\section{Early marriages and some important figures}

When our fieldwork took place, there were no available statistics on the breakdown of early marriage by ethnicity in Romania however we can argue, based on assumptions and NGO reports, that early marriages are frequent among the conservative traditional Roma communities. Following surveys by

\footnotetext{
${ }^{5}$ Romania's top priorities include encouraging Roma children to participate in early childhood education and care, promoting entrepreneurship among the Roma and tackling problems of indebtedness. Romania's national Roma integration strategy aims to eliminate poverty and social exclusion through targeted education, employment, healthcare and housing policies. The strategy's objectives include ensuring that Roma children go to school, with a special focus on girls, and ending segregation in schools. It also aims to improve the Roma's access to public services and basic infrastructure. See the text here: http://www.anr.gov.ro/docs/Strategie_EN.pdf

${ }^{6}$ EU Funding for Roma integration in Romania. For the $2014-2020$ period, Romania will be allocated $€ 22.9$ billion in EU funds, out of which $€ 15.95$ billion will come from the European Social Fund (ESF) and the European Regional Development Fund (ERDF). Of this amount, at least 30.8\% will be spent on the ESF, with at least $20 \%$ of that going towards the promotion of social inclusion and combating poverty. https://ec.europa.eu/info/policies/justice-and-fundamental-rights/combattingdiscrimination/roma-and-eu/roma-integration-eu-country/roma-integrationromania_en\#nationalstrategyforromaintegration

${ }^{7}$ Interview with policy maker, T. Mures,

${ }^{8}$ Interview with policy maker, T. Mures,
} 


\section{Velentza}

the Institute of Research of the Quality of Life (2002), 35\% of the Roma women marry before the age of $16 ; 31 \%$ of them married at the age of 17-18, $26 \%$ married at the age of $19-22$ and only $8 \%$ after the age of 22 . There is an increase to $84 \%$ for Roma girls who marry before the age of 20 (for the age group of women between 20 and 24 years old).

- According to the survey, $40 \%$ of Roma couples live in non-registered marriage, it can reach $83 \%$ for girls married at the age of $15-19.37 \%$ of Roma girls have babies before 18 years.

- No statistics are available on the number of arrests of adults conducting early marriages or on the number of early marriages generally within the traditional Roma communities.

- It is difficult to obtain exact data on the number of minors leaving compulsory education.

- In the traditional communities' girls drop-out is estimated at the age of $11-12$ years $\left(3^{\text {rd }}-4^{\text {th }}\right.$ grade $)$ and boys at the age of $13-15$ years $\left(6^{\text {th }}-8^{\text {th }}\right.$ grades).

\section{Roma children and education in the municipality of Mureş ${ }^{9}$ : figures provided}

According to data collected for our research, these are the figures available for Roma students enrolled in education (updated until 2012):

\begin{tabular}{cccc}
\hline Education level & $\begin{array}{c}\text { Number of } \\
\text { Roma students }\end{array}$ & $\begin{array}{c}\text { Total number } \\
\text { of students }\end{array}$ & Percentage \\
\hline Kinder gardens & 2.063 & 21.768 & $9,47 \%$ \\
\hline Primary education & 4.464 & 24.433 & $18,27 \%$ \\
\hline $\begin{array}{c}\text { Secondary } \\
\text { education }\end{array}$ & 2.784 & 22.334 & $12,46 \%$ \\
\hline Universities & 562 & 19.692 & $2,85 \%$ \\
\hline
\end{tabular}

For the period 2011-2012, 87 out of 202 positions specifically dedicated to Roma children were covered at the universities of Romania which is under covered and choose to be enrolled under the generic scheme for Romanian students to avoid being discriminated. Most of them decided to study sociology, tourism, humanitarian sciences, as well as natural sciences. In Mureş municipality where our fieldwork took place, there are 18 teachers of Romani language (it appears insufficient for the existing needs) and only 7 cultural mediators on education. The biggest challenge for Romani teachers is to be able to correspond to the needs of a high number of students, and for children to be able to preserve Romani language, as most of them are enhanced by family to choose Hungarian language as their mother tongue. The reason why is that

9 You can check data from Ministry of Education, municipality of Mureş: http://www.edu.ro/index.php/base/frontpage

*TPLondon.com/JGS 
the state gives them benefits in order to promote Hungarian language as a means to promote the Hungarian minority in Transylvania region. The Hungarian party representing the Hungarian minority has set as a goal: the promotion of Magyar (Hungarian), their mother tongue within next years. ${ }^{10}$

\section{Our findings from our fieldwork in schools of Mureş region}

Our fieldwork in the schools was facilitated by the personnel of Liga Proeuropa, working under the program Daphne III ${ }^{11}$ for the prevention of early marriage funded by the EU and Education Fund ${ }^{12}$. Based on social observation and meetings with Roma children and their parents in different primary schools in the region of Mureş, we observed that kids belong either to marginalized Roma communities (our field work took place at the villages of Glodeni, Petelea, Band, Valeni and the city of Tírgu Mureş (in areas and suburbs outside the main town such as San Georgescu and Tudor where considerable numbers of traditional Roma community live). Throughout these meetings, we had the opportunity to meet mainly Roma teachers whose native language is Romani or Hungarian, such as schools in San Georgescu or Tudor. It is understood that it an ongoing challenge for Roma community to preserve their native language, Romani language, as it is either not taught in every school or Roma parents prefer that their children speak Hungarian as main language for more opportunities and in order not to be discriminated. In addition, it is a challenge to persuade parents about the importance of educating their children and sending them to universities.

Based on the findings and discussion with members of the community, we confirmed the argument that the practice of early marriage is a tradition, a "valuable custom" within the traditional Roma communities (Kaldarashi, Gabor, Turkish Muslim Roma communities). Early marriage is a determinant factor giving a strong sense of identity, by preventing potential harmful experiences for the girls from externals and keeping the group united and compact. The children learn their role in the community at an early age. For all these reasons, one of the challenges throughout our research was that in order to discuss and

${ }^{10}$ Report of UNDP, Romania: http://www.unpo.org/article/14175

11 Daphne III program has as main goals to combat early marriage amongst traditional Roma communities and financed by EU justice fund (annual budget 18,5 M euro). It is implemented along with Bulgaria, Romania, Greece in partnership with Bulgaria, Romania and Greece in cooperation with AMALIPE center, Bulgaria (http://amalipe.com/index.php?nav=home\&lang=2 www.romanibori.com), Liga Proeuropa, Tírgu Mureş in Romania and NGO Arsis in Greece (http://www.arsis.gr/) and aims to foster partnerships of NGOs, networks, associations, local authorities, activists, policy makers, Roma families. Program aims to raise awareness about early marriage, promotion of education, discrimination combat, tolerance, promotion of participation of Roma parents and authorities in campaigns, protection of human rights, respect towards women. Mediators usually come from the same community in close cooperation with local authorities. http://ec.europa.eu/justice/fundamental-rights/programme/daphne-programme/index _en.htm \& http://ec.europa.eu/justice/grants/programmes/daphne/

12 Program on "education for Roma children - a route to a safe job" under the responsibility of the National agency for Roma people and funded by European Social Fund to prevent social exclusion and marginalization of children who are in early marriages, especially girls. See more here: http://ec.europa.eu/esf/home.jsp?langId=el \& www.romaeducationfund.ro. 
elaborate this issue with the community members, community leaders should be part of the process and interlocutors with the responsible national and local authorities.

Finally, based on our interviews with some of the mothers of Roma children in the communities we had the opportunity to visit, it is understood that early marriage is a "taboo" for traditional Roma communities, as lots of mothers were reluctant to refer to the values of the communities in a negative way, it rather seems that most of them recognize the importance of education, and this is proved by their willingness that their children continue their education at university level. The majority of the children who engaged in our project (young boys and girls) seemed to be aware about the institution of early marriage and the consequences it has in children's lives. Out of seventy kids that we met only two girls expressed the will to conduct an early marriage and therefore to drop education.

The majority of children we discussed with (age 5-14) argued that early marriage would mean for them deprivation of their freedom, their economic independence (this was partly expressed by young girls), deprivation of family and friends, education drop out and fewer opportunities to enter labor market. Most of the girls opposed the idea to become housewives or give birth at an early age. It must be underlined that they were reluctant to refer to themes such as sexual relations, sexual education and gender, contraception measures, impact of early pregnancy, interpersonal relations, engagement in discussions on early marriage with their parents. This was also the case when we referred to the so-called tradition of virginity testing, applied also in some traditional Roma communities in Greece.

Community centers exist in the region of Mureş with the aim to provide free primary education (Romani language, mathematics, literature) to Roma children who have no means to enter school. One of these centers which we visited for our research was Curcubeu Center in a marginalized community outside the city of T. Mureş (Curcubeu means rainbow in Romani language). The aim of the center is to educate children of poor and marginalized Roma community in a marginalized area called Valea Rece (Cold Valley) at the suburb of Tírgu Mureş. This happened after consent of the community where illiteracy rate reached $70 \%$. Early marriage, impoverishment, discrimination, social exclusion is some of the characteristics of the community. In addition, we had the opportunity to visit the local traditional craft.

\section{Our findings based on interviews with representatives from national authorities and community leaders}

The case of 13-year old Anna-Maria Cioaba's marriage became known in 2003, the luxurious marriage of Mr Cioaba's daughter attracted unprecedented media coverage. The marriage, attended by high ranking guests (including a 
former Minister of Interior) came to the attention of the European Commission Committee on children's' rights. Since then, the problem of early/forced marriages in Romania became known and public policies and strategies were adopted. The late Florin Cioabă, the so called "King of Roma"13 stated at that time that "any change regarding this practice and changing mindsets could come only by the communities." $14 \mathrm{He}$ also stressed that "early marriage is strongly connected with Roma traditions which go back thousands of years ago" and was reluctant to comment on his minor child's marriage.

When our meeting took place in Bucharest, we understood that the official elected political party representing the Roma population in Romania ${ }^{15}$, was not able to impact Roma peoples' lives and this was demonstrated by the low percentage in the last elections however the party was proactive to proceed with several legislative initiatives in favor of women and girls rights, abandonment of early marriage practice and involvement of children in education especially girls. These initiatives at legislative level prove that, although insufficient, there is political will at policy making level and this is a positive step towards modernization of the traditional Roma communities in the region of Transylvania.

Most of interviewees stressed that strengthening relations between the current government and the communities is needed as the government appears to be very popular for its anti-Roma rhetoric. An outcome of our discussions is that strengthening relations with Roma communities at local level along with integration for so called "traditional" Roma people, access to education, health services, labor market, social security, human and dignified living conditions, empowerment of girls and women and development are some of the big challenges at policy level.

Access to education and health services is a primary challenge for Roma community, which was also underlined by the then President of National Agency for Roma community in Bucharest, Ilie Dinca. He argued that more funding for education from the European Union and donors is necessary. In terms of early marriage, other traditional practices and education drop out, he clearly said that "I condemn the practice of early marriage as it violates EU and international human rights norms but you have to understand that as Roma people we have to conserve our traditions, traditions that go back thousands of years ago." "We don't want

${ }^{13}$ In 1992, Iona Cioabă self-proclaimed himself as 'The King of Roma Everywhere' 'in front of 1.000 Roma according to his son. His son, Florin Cioabă, succeeded him after his death. He was succeeded as a king by his son, Derin. https://en.wikipedia.org/wiki/Florin_Cioabă

14 You can see more here: http://ec.europa.eu/justice/fundamental-rights/rights-child/index_en.htm

${ }^{15}$ Partida Romiilor is the official party which represents the Roma community at governmental level. It was formed in 19.03.1990. According to the Romanian electoral law, every minority has to elect tis representatives at governmental level. Art. 9 of the funding principles of the party foresees that maintenance of tzigane culture as well as education through Romani language are some goals since its establishment. See more here: http://partidaromilor.ro 
our traditions to be gone" and that" The change to this norm can come only by the community itself.

\section{Our findings based on interviews with civil society representatives ${ }^{\mathbf{1 6}}$}

A considerable number of NGO representatives, members of civil society and researchers in Romania accept that early marriage within the Roma community is not related to any norms, it is connected to the ethnicity and social organization of the community. ${ }^{17}$ It is rather linked to existing poverty in the communities as well as the willingness of girls to escape parents' home and it is seen as a means to gain prestige and become from a girl to a woman. In addition, it is wise to make a link between early marriage and education dropout: there is a cause- result link ("These two go hand by hand") ${ }^{18}$ and it is not a characteristic of all Roma communities, that's why it should be examined case by case.

Following our meeting with Maria Koreck, President of NGO-Intercultural Center for Roma in Tírgu Mureş, Divers ${ }^{19}$ we understood that in early marriages not the majority of Roma people in Romania is involved which leads us to the conclusion that lots of Roma families have taken steps to modernize and integrate into Romanian society, especially she states: "The early marriage only concerns a small number of traditional Roma communities and not the majority of Roma people in Romania this tends to be a "very stereotypical way of thinking". Early marriage is seen as a way for traditional parents to protect their children and is based on Roma culture in order to protect their children from 'third ones'. External intervention in the traditional communities regarding the early marriage phenomenon should be done with "extreme discretion". She continued that education drop-out is inter-linked with the early marriage phenomenon." A challenge is for young girls and boys to "Create good examples in the community".

At this point, we understood that empowerment, education, employment opportunities and non-discrimination can create incentive for Roma children

${ }^{16}$ National Council against racism (NCCD) is the responsible agency to take submission of cases of racism but is not responsible to proceed with these cases. Cases concerning Roma are usually put forward by NGOs working with Roma communities and reach 20-15\% (2011). Sanctions can reach up to 1.400 euro in case there is a damage to individuals and 1.800 euro in case there is a damage to the interests of a community. In case the judgement is not enacted, there is a possibility to proceed to the civil courts and claim compensation for the harm done, decision should be awarded in 90 days after the claim. See more here: http://www.cncd.org.ro/?language=en $\quad \& \quad$ http://www.errc.org/en-searchresults.php? mcountry $=173 \&$ mtheme $=1 \&$ marea $=1 \&$ mkeyword $=$ early + marriage $+\& o k=\mathrm{OK}$

Liga Proeuropa statement against early marriage as a form of violence against women and children, addressed to the UN: www.ecpi.ro/wp-content/uploads/2012/08/CSW_Communication_ ECPI_ RomaniCRIS_PROEUROPE-League_Romania_2012.pdf

See report here of NGO Romani Crisis on cases of racist violence against Roma, Submission to UN Universal Periodic review: http://www.romanicriss.org/PDF/Written $\% 20$ submission $\% 20 U P R \% 20$ Romania_Romani\%20CRISS.pdf

${ }^{17}$ Interview with Prof Enicö Vincze, Expert in gender and minorities studies in the University of BabeşBolyai, Cluj-Napoca.

${ }^{18} \mathrm{Ibid}, 14$.

${ }^{19}$ See more here: http://www.divers.org.ro/

TPLondon.com/JGS 
so as not to get married at an early age and feel marginalized. Specifically, our interviewee working in the area of Bucharest stated that "Education is crucial and determines the prevention of early marriage in the Roma communities" and some of the challenges for them is preservation of their own culture." Along with that, preservation of their native language is important "Speaking and writing in Romani language is the biggest challenge" and at the main time "Access the labor market and more employment opportunities for the Roma people is the main priority that the civil society has undertaken while working with Roma people". ${ }^{20}$

Representatives from civil society and activists working on rights for the protection of Roma girls and women as well as victims of gender-based violence, racism and domestic violence ${ }^{21}$ refer to early marriage as a factor of social exclusion and drop out of primary education. Some of them argue that: "Early marriage is a very complex issue and represents two sides of

the same coin: on the one hand lack of respect for children's rights is unacceptable but on the other hand there is a need to respect the community's rules and principles". "We cannot stop it but what we can do is to convince the leaders not to let the children get married early. "

From the above, we consider that through creative dialogue, it is important that community leaders are convinced not to allow marriages of children under 18 years old and to enhance them to continue their education in school. Continued dialogue, continuous education of communities and interaction and coordination from institutional authorities are the preconditions towards this direction.

The argument that traditional Roma communities relate early marriage with traditional values of the community which can lead to a health and sustainable family for traditional communities is also expressed by the President of NGO Pakiv Association ${ }^{22}$, Mr Gruia Ioan Bumbu based in Alba Iulia, the first capital of Transylvania region and "a means of support between Roma families and denial of traditional Roma to move from tradition to modernity". Their denial to adopt values and principles of modern world is and living in "dictatorial parallel society" is a conscious choice.

He also argued that "After the "90s the Roma people were the biggest losers in the Romanian society" meaning that any attempts to integrate them failed and also stressed the significance of access to labor market and equality to Romanian citizens. "After the 2000s the Roma people were subjected to discrimination based on their lack of participation in the economic life of the country they live". In addition, he argued that it is indispensable that "The Roma communities should be part of a full inclusion process in the Romanian society and not an integration-based process". Moreover, he states

\footnotetext{
${ }^{20}$ Interview with Amelia Gorcea, Porogram Officer, The Ethno-Cultural Diversity Resource Center www.edrc.ro

${ }^{21}$ Interview with several activists from civil society organizations Roma Center, EDRC and Romani Crisis. See more here: www.Romacenter.ro www.Edrc.ro www.romanicriss.org

${ }^{2}$ Pakiv in Romani language means trust, respect. See more here: http://pakiv.ro/
} 
that "For a person living in extreme poverty, it is hard to talk about empowerment and emancipation of his/her right, as his/her primary goal is survival". ${ }^{23}$

Based on our findings, it is our opinion that social environment does not help young Roma girls to emancipate and get away from Roma traditions such as early marriage, and this is due to lack of efficient education and insufficient integration in Romanian society. There is a legal precedent of punishment of parents or adult- husbands who are in charge of early marriage in front of Romanian judicial however there is no enforcement of judgements or there is little talk about this issue. ${ }^{24}$ Within the Political Science Department, Professor Andreescu has done extensive work on that particular thematic.

From our discussion, it is understood that the argument that "early marriage is seen as a means to preserve the young girl's virginity and purity should not be regarded valid." According to a survey conducted in 2005, 1 million expected to define themselves as Roma and it has always been a reality that there are political Roma leaders who want to create a "Roma nation" within Romania. The only solution suggested for Roma community is that the state should react by educating them more and more otherwise "The Roma community will be always captured in its traditions." Another argument against early marriage based on the outcomes of the research is that it is a justification of established patriarchy within the traditional Roma communities enforced by community leaders and men within them "We should not legitimize early marriages through the argument that this is a means to preserve the girl's virginity, it is mostly a justification for gender equality, less rights for women and girls and of the assumption that it is a normality that a woman is subjected to a man's power'.' It is stated that "early marriage is a way to be manipulated as a girl and be susceptible to her husband or his family's power, obeying them without questioning and being a wife following the community's values."

From the above, another observation is that "Traditional Roma people struggle for their daily survival, a great challenge for them is to be open enough and be real examples for their children" especially Roma women face big struggles and they really want to be role models for their children, they want to "the best mothers in the world, they love their children so much and they want the best for them." "In the traditional communities, honor and respect are the

\footnotetext{
${ }^{23}$ Interview with Dr Gabriel Andreescu, Professor of human rights, gender and minorities in the Political Science Department, University of Bucharest. He is also a Romanian activist, political scientist and supporter of human rights, minorities, multiculturalism and religious freedom in the University of Bucharest. He is the editor of the journal Noua Revista de Drepturile Omului, previously Revista Romana de Drepturile Omului. You can see here more: http://en.wikipedia.org/wiki/Gabriel_Andreescu \& http://www.ujm noua-revista-dedrepturile-omului ag.ro/reviste/

${ }^{24}$ There is no official data about the cases according to our research and based on our interviews it seems that the majority of court cases is not executed. 
most basic values. There are no values with regards to education and not open mind and spirit to modern values." 25

\section{The necessity to create a role model in Roma youth is a prerequisite for fewer early marriages}

During our interview in T. Mures, Rudy Moca" says "I am prond to be a Roma”. Rudy Moca is a popular artist, actor and intellectual who promotes art, poetry and culture of Roma people living in Romania, at national and international level. Mr Moca's motivation to start working with Roma people, as Roma himself, was his wife who convinced him to publish his first article on Roma culture after reading an article on the projected negative sides of Roma life; that's how it started 40 years before. He is considered as an outstanding model in his community. However, he tries to convince his community that he managed to be successful after lots of work, commitment and personal struggle, and motivates and empowers them through his art.

His observation is that Roma people and youth feel humiliated and inferior to the "gadjos" sometimes tend to have low self-esteem. "The main challenge for civil society and politicians, is to change mentalities, he continues. "Critical for his views, Mr Moca, promotes Romani culture and blames the inefficiency of the existing state institutions to educate properly the Roma community. Promoting mutual understanding between the Roma people and the "gadjos" is his message. He says that "We understand that Roma youth needs good role models to improve their social status in society and not feel marginalized and inferior to members of society who do not belong to their community (gadjo, gadjie, gajo 27 )." And this could be achieved through education of communities and understanding of Roma values in order to obtain a better future in Romanian society.

\section{Empowerment of women and gender-based violence in traditional Roma communities}

Traditional Roma communities often are reluctant to talk about issues considered taboos such as sexual relations, domestic violence and gender equality. Based on our data from our fieldwork in Beraca Foundation on prevention of domestic violence in Sighişoara ${ }^{28}$, we understood that genderbased violence prevention programs have contributed to awareness-raising as well as individual and family counseling on health issues, gender, domestic

${ }^{25}$ Interview with Mihaela Kovacs, Sociologist and Founder of the Beraca Foundation.

${ }^{26}$ His official page can be found here: htpp://rudymoca.blogspot.ro

27 The term trigane originates from the Greek word afizyavos, atoizyavos (athinganos) which means untouchable and probably comes from the term of the lowest cast in India, where it is believed that Roma

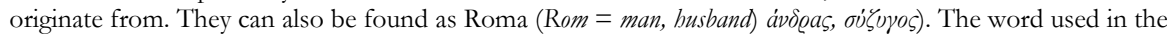
text means someone who is a person who is not an ethnic Romani, an ethnic Romani who lives outside the Romani culture, an "outsider" someone outside the community so he is automatically a "foreigner" (gadjo, gadgie, gajo).

${ }^{28}$ Ibid, 22. 
violence and abuse (physical, sexual, emotional, moral and verbal), children's rights, family planning and having being very beneficial. They managed to lift self-esteem for women in traditional Roma communities with a typical patriarchal structure. It is also stated that combating perceptions that domestic violence "exists into the blood" of Roma men is an imperative. Some of the concerns raised had to do with the fact that Roma people are very proud people and do not let anyone in their traditional family structures "It took a long time for women in the Roma communities to accept that domestic violence is a real problem and it should be dealt with seriously. The communities rarely accept intervention from foreigners and NGOs to deal with their personal problems". One of the goals of these programs is promoting parental education and raising awareness in order to increase selfesteem for Roma women and it had some successful results in some communities.

\section{Final remarks}

Based on data from fieldwork and our analysis, we argue that early marriage in some traditional Roma communities in the area of Transylvania is a strong tradition, a valuable cultural practice as it is a determinant factor to construe their national identity. Moreover, the Roma communities who practice this consider it to be a means of protection of the young girls, their purity simultaneously it is a protection from foreigners, the bad white ones, and a way to learn their tasks and enhance their role within the community. Early marriage, against children' consent, can have unwanted results such as early pregnancies for the young girls, less rights, marginalization and domestic violence in some cases. Early marriage can be a cause of education drop out for young impoverished children in these traditional communities we visited.

In conclusion, it is our opinion that early marriage could be approached in cooperation with national, local authorities, community leaders and members of Roma communities. National authorities and political parties are responsible to raise awareness and undertake campaigns of sensitization of the matters already discussed.

Moreover, full implementation of programs and supporting strategies at public sphere, mutual trust and dialogue between the communities and responsible authorities as well as openness of approach and mutual understanding of traditions are indispensable for the protection of rights of the communities and social cohesion within the Romanian society.

The fact that early marriages still take place in some regions in Romania as well as the lack of proper and adequate implementation of European programs in favor of Roma community demonstrate a need for the civil society to be more active and cooperate with all stakeholders and communities involved, as well as involvement of political actors and policy makers, implementation of mechanisms in an effective and efficient way. Adopting policies in favor of 
traditional Roma community in the region of Transylvania and preserving their well-being, their cultural identity and creating mutual trust in society must be in the core of the political agenda. The role of civil society appears crucial. It is a continuous challenge for Romanian society to build upon trust and prevent marginalization and exclusion of the Roma community in Romanian society.

\section{References}

Amalipe Center for Interethnic Dialogue and Tolerance (2011). Preventing early marriages, Veliko Tarnavo, 2011. [http://amalipe.com/files/publications/ranni\% 20brakove\%20last.pdf]

Amalipe Center for Interethnic Dialogue and Tolerance (2011). Women Destinies several usual stories of unusual Romani women, their battles, and victories, tears and joys, published with the financial support of Daphne III Programme funded by the European Commission, Veliko Tarnavo. [http://amalipe.com/files/ publications/ jensky_sydbi_eng_1.pdf]

Barbu Daniel (2011). Roma and the Public Discourse in Romania best practise guidelines lines (Romii în discursul public românesc Îndrumar de bune practici), Romani Criss Roma Center for Social Intervention and Studies, Bucharest.

European Roma Rights Centre (ERRC) (2011). Breaking the silence A Report by the European Roma Rights Centre and People in need - Trafficking in Romani communities, Budapest, March 2011. http://www.errc.org/

Gergely Dezideriu (2002). Good practices: Compilation of court cases of discrimination against Roma in access to public places, A comparative study on national and international court cases of discrimination, legislation and specialized bodies in combating discrimination, Romani Criss Roma Center for Social Intervention and studies with the support of the OSCE Office for Democratic Institutions and Human Rights (ODIHR), Editura ECA, Cluj, April 2002.

Harda, Stefen Iulian and Macovei, Razvan Ionut (2007). Public policies for Roma in Romania (Politici publice pentru Romi în România) 2000-2005 - Legislative framework, institutions, programmes, achievements and expectations, work coordinated by the President of the National Agency for Roma, Mr. Ilie Dinca and published with the financial contribution of the European Commission through the Communitary Action Program for Combating Discrimination (2001-2006), Bucharest.

Kacsó, Judit-Andrea, ed. (2007). Diversity and Social Cohesion Equal Participation of Minorities in Europe: The Role of Intercultural Education, Project Partner's Meeting Report in Bucharest 15-18 February, Tárgu- Mureş.

Magyari-Vincze, Enikö (2006). Social exclusion at the crossroads of gender, ethnicity and class A view through Romani Women's reproductive health (Excludera socială la intersectia dintre gen, etnicitate şi clasă $\mathrm{O}$ privire din perspectiva sănătăţii reproducerii la femeile Rome) Research paper with policy recommendations, Editura Fundației pentru Studii Europene, Cluj.

Magyari-Vincze Enikö, Wamsiedel, Marius and Ionescu, Iustina (2012). Roma health perspective of the actors involved in the health system-doctors, health mediators and patients, published with the support of Romani Crisis-Roma Center for social intervention and studies, Bucharest. 


\section{Velentza}

Magyari-Vincze, Enikö (2003). Talking feminist institutions interviews with leading european scholars, Editura Fundaţiei Desire, Cluj. [http://www.ccrit.ro/Pdf/ StudentReviews /PetrutaMindrutReviews/MAGYARI_VINCZE_Eniko.pdf]

Morteanu, Madalin Matache, Margareta Mandanche, Marian, and Mihalache, Cristi (2007). Legal protection against discrimination and public policies towards Roma, Romani Criss Roma Center for Social Intervention and Studies, Bucharest.

Ovidiu Pecican Colecția proiecte pentru Romi (2011). Studii despre Romi Egalitate prin Diferență albumul proiectului, Editura Fundației Desire, Cluj.

Proeuropa Ligue, Human Rights Office (2011). Early/forced marriages in Romania, Country Report and Case Study on Racial Discrimination in Mureş county, TárguMureş. [http://www.proeuropa.ro/full.html]

Romani Criss Roma Center for Social Intervention and Studies (2004). Annual report 2003 Respecting human rights in Romania: Roma citizens of the state of law, Bucharest.

Romani Criss Roma Center for Social Intervention and Studies (2010). The Implementation of human rights from discrimination against Roma to law enforcement abuses, Report on actions of monitoring, promotion procedurs and defence of human rights in Romania, Bucharest.

Surdu, Laura Vincze, Enikö and Wamsiedel Marius (2011). Roma school participation, Non-attendance and Discrimination in Romania with the support of UNICEF, Bucharest. 